\title{
Thrombocytopenia and Congenital Syphilis in South African Bantu Infants
}

\author{
IDA FREIMAN and M. SUPER \\ From the Department of Paediatrics, Baragwanath Hospital, and \\ University of the Witwatersrand, Johannesburg, S. Africa
}

The causes of thrombocytopenia in the newborn and young infant differ from those of older children and adults. Maternal antibodies, platelet sequestration during haemolytic disease of the newborn, and thrombocytopenia following replacement transfusion with stored blood, bacterial septicaemia, and spirochaetal and protozoal infections are important causes of neonatal thrombocytopenic purpura. It may be a feature of the congenital aplastic anaemia associated with certain anomalies of bone, while in a proportion of cases the aetiology remains obscure.

Syphilis as a cause of neonatal thrombocytopenia has not been emphasized and is either not mentioned in standard works of haematology (Britton, 1963; Wintrobe, 1961) or is cited as a rare association (Mandel, 1962).

Our interest in the problem was first aroused by 2 cases of congenital syphilis associated with bleeding, thrombocytopenia, and anaemia. Although congenital syphilis is seen fairly frequently at Baragwanath Hospital, it was our impression that thrombocytopenia was rarely associated with this disease. A study was undertaken to assess the incidence of thrombocytopenia in syphilis, and to clarify the importance of syphilis as a cause of bleeding in newborn and young infants.

\section{Material and Methods}

A prospective investigation for thrombocytopenia was carried out in all cases of congenital syphilis presenting with anaemia, purpura, or bleeding, seen over a period of 18 months. The criteria for the diagnosis of congenital syphilis were clinical features consistent with syphilis and positive serology in either the mother or the child.

Serological tests for syphilis in infants under the age of 6 months are considered unreliable, as there may be a passive transfer of antibodies to the foetal circulation, or a failure of the infant to develop antibodies in early infancy. Therefore, wherever possible, the maternal blood was studied.

\footnotetext{
Received June 14, 1965.
}

Laboratory investigations on samples of venous blood included haemoglobin estimations, reticulocyte counts, and platelet enumeration by the direct method (Dacie, 1956). A platelet count of less than $100,000 / \mathrm{c} . \mathrm{mm}$. was considered abnormal. Red cell, white cell, and platelet morphology in the peripheral blood and bone-marrow were studied on films stained with Wright's stain. The Venereal Disease Reference Laboratory (VDRL) flocculation test for syphilis was performed by the technique described by Shaffer and Goldin (1962).

Bilirubin concentration was measured by the method of Lathe and Ruthven (1958). Blood cultures, toxoplasma complement-fixation and dye tests, and urine examination for cytomegalic virus were carried out in all cases.

\section{Results}

Over a period of 18 months congenital syphilis was diagnosed in 46 infants. Of these, 13 babies under the age of 3 months were found to have thrombocytopenia. During the same period, thrombocytopenia, unassociated with syphilis, was found in 9 infants in the same age-group. Platelet antibodies were thought to be responsible in 2 of them. 2 children had salmonella septicaemia, and in yet another child, the thrombocytopenia was associated with bilateral renal vein thrombosis and uraemia. In 3 infants, the cause of the thrombocytopenia was obscure, and the ninth child died before being adequately investigated.

\section{Case Reports}

The following are detailed case descriptions of the first two infants studied in this series and are fairly typical (Tables I and II).

Case 12. This premature first-born infant was admitted at the age of 6 weeks weighing $4 \frac{1}{2} \mathrm{lb} .(2 \cdot 20 \mathrm{~kg}$.). $\mathrm{He}$ had failed to thrive despite adequate breast-feeding. Malaena was present, and the infant was found to be severely anaemic. Hepatosplenomegaly and an exfoliative rash of the palms and soles were present. The 


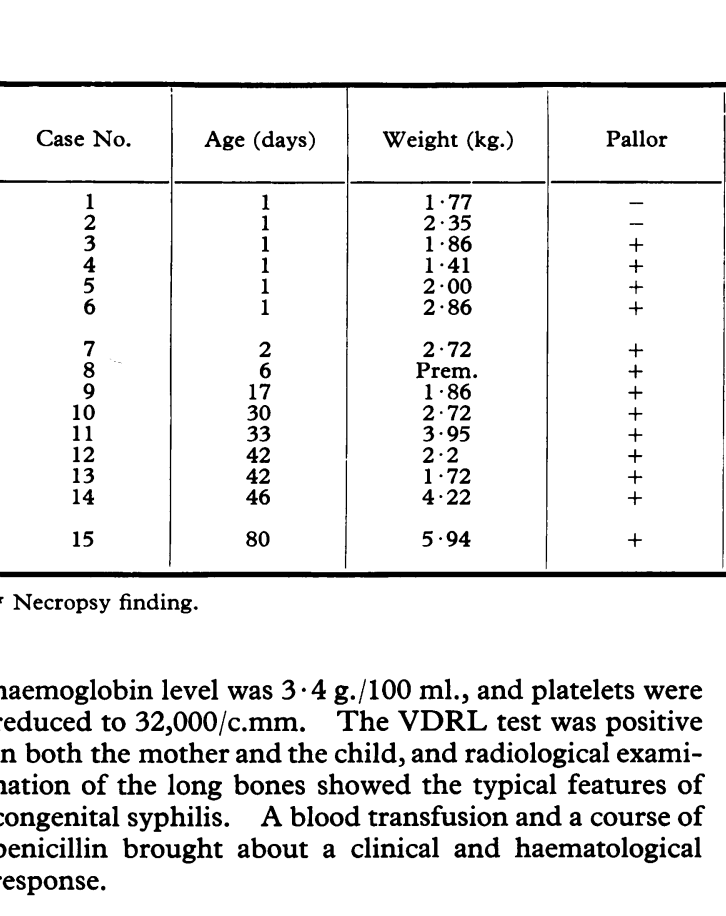

Case 14. The second child of a mother with a normal obstetrical history, he was a full-term infant who had thrived well until shortly before admission. At the age of 6 weeks he became jaundiced and developed convulsions. Examination showed a child with 'snuffles', nasal bleeding, mild jaundice, and moderate pallor. The liver and spleen were both enlarged and a scrotal rash was noted. Shortly after admission, oedema of the lower extremities developed. The haemoglobin level was $5.4 \mathrm{~g} . / 100 \mathrm{ml}$. and platelets were reduced to $25,000 /$ c.mm. The serum bilirubin was $2.6 \mathrm{mg} . / 100 \mathrm{ml}$. with a direct fraction of $2.4 \mathrm{mg} . / 100 \mathrm{ml}$. There was an

albuminuria, and microscopical haematuria was noted. The CSF was normal. Radiological examination of the long bones showed the osseous changes of congenital syphilis, and the VDRL test was positive in both mother and child.

Table I summarizes the clinical features of the 15 cases of thrombocytopenia associated with congenital syphilis. The ages ranged from 1 to 80 days. A low birth weight was found in 9 babies, of whom 2 , aged 6 weeks, had failed to thrive. Bleeding and gross anaemia were features in 10 cases and purpura was present in 4 of these. Those patients who did not show overt haemorrhage had petechiae with the exception of one (Case 15, Tables I and II), where thrombocytopenia was found on routine examination into the cause of an anaemia. The liver or the spleen or both these organs were enlarged in all cases. Typical skin rashes were present in 11 and

Spleen:

Bruising, haematoma

Nose

Peritoneal

Melaena

Nose and mouth

- hs

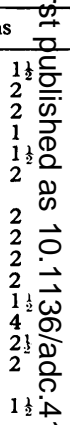




\begin{tabular}{|c|c|c|c|c|c|c|}
\hline \multirow{2}{*}{ Rash } & \multirow{2}{*}{$\begin{array}{l}\text { Bone } \\
\text { Changes on } \\
\text { Radiograph }\end{array}$} & \multirow{2}{*}{ Other Features } & \multicolumn{2}{|c|}{ Flocculation Test } & \multirow{2}{*}{ Alive } & \multirow{2}{*}{ Dead } \\
\hline & & & Mother & Baby & & \\
\hline $\begin{array}{l}\text { Peeling palms and soles } \\
\text { Copper-coloured } \\
\text { Peeling palms and soles } \\
\text { Peeling palms and soles } \\
\text { Peeling palms and soles } \\
\text { Peeling palms and soles } \\
\text { - } \\
\text { Peeling palms and soles } \\
\text { Peeling palms and soles } \\
\text { Peeling palms and soles } \\
\text { Peeling palms and soles } \\
\text { Coppery, on scrotum }\end{array}$ & $\begin{array}{l}+ \\
- \\
+ \\
+\end{array}$ & $\begin{array}{l}\text { Jaundice, raised direct bilirubin } \\
\text { Jaundice, raised direct bilirubin } \\
\text { Jaundice } \\
\text { Jaundice, raised direct bilirubin, } \\
\text { hydrocephalus } \\
\text { Jaundice, raised direct bilirubin } \\
\text { Failure to thrive } \\
\text { Fits, failure to thrive } \\
\text { Fits and nephritis; jaundice } \\
\text { raised direct bilirubin }\end{array}$ & $\begin{array}{l}+ \\
+ \\
+ \\
+ \\
+ \\
+ \\
+ \\
+ \\
+ \\
+ \\
+ \\
+ \\
+\end{array}$ & $\begin{array}{l}+ \\
+ \\
+ \\
+ \\
+ \\
+ \\
+\end{array}$ & $\begin{array}{l}+ \\
+ \\
+ \\
+ \\
+ \\
+ \\
+ \\
+ \\
+ \\
+ \\
+ \\
+\end{array}$ & $\begin{array}{l}+ \\
+\end{array}$ \\
\hline
\end{tabular}

consisted either of marked peeling of the palms and soles, or copper-coloured cutaneous plaques or circinate lesions. Radiographs showed periostitis and metaphysitis of the long bones in 6 of 7 children in whom this examination was carried out. Jaundice was observed in 6 children. The VDRL test was positive in all the mothers tested (13) and in all the infants tested (9).

The results of haematological investigations and other relevant data are summarized in Table II. All 15 infants were anaemic according to the average haemoglobin range quoted for normals in the various age-groups (Smith, 1960). The haemoglobin levels ranged from 3.4 to $10.3 \mathrm{~g} . / 100 \mathrm{ml}$. in infants over the age of 1 week and from $12 \cdot 1$ to $16.5 \mathrm{~g} . / 100 \mathrm{ml}$. in the remaining infants in whom haemoglobin estimations were carried out on the first day of life. The reduction in haemoglobin was accompanied either by a reticulocytosis ranging from 5 to $19 \%$ in 8 infants or by poikilocytosis and anisocytosis. After taking into account the normal range of white cells for the age, 11 showed a leukaemoid reaction. Counts ranged from 9,000 to $64,000 /$ c.mm. Immature white cells and occasionally blast cells were prominent in the peripheral blood films, especially when the white cell count was high. Blood films of 12 infants showed scanty platelets. Platelet counts were reduced to below $50,000 / \mathrm{c} . \mathrm{mm}$. in 11 , and ranged between 50,000 and $100,000 / \mathrm{c} . \mathrm{mm}$. in 3 infants. In one infant a platelet count was not done (Case 13).

Bone-marrow aspirates were studied in 8 ; of these 4 showed an amegakaryocytic picture, 3 the presence of scanty non-budding megakaryocytes, and 1 showed many non-budding megakaryocytes. The other bone-marrow elements were normal, except in

and Liver Histology

\begin{tabular}{|c|c|c|c|c|c|}
\hline \multicolumn{2}{|c|}{ Smears } & \multirow[b]{2}{*}{ Polychromasia } & \multicolumn{2}{|c|}{ Bone-marrow } & \multirow{2}{*}{ Liver Histology } \\
\hline Platelets & Aniso-poikilocytosis & & Cellularity & Megakaryocytes & \\
\hline $\begin{array}{l}\text { Scanty } \\
\text { Scanty } \\
\text { Scanty } \\
\text { Scanty } \\
\text { Scanty } \\
\text { Scanty } \\
\text { Scanty } \\
\text { Scanty }\end{array}$ & $\begin{array}{l}- \\
\overline{+} \\
+ \\
+ \\
+ \\
+ \\
+ \\
+\end{array}$ & $\begin{array}{l}- \\
- \\
+ \\
+ \\
+ \\
+ \\
+ \\
+\end{array}$ & $\begin{array}{l}\text { Average } \\
\text { Average } \\
\text { Average } \\
\text { Average }\end{array}$ & $\begin{array}{c}\text { Scanty } \\
- \\
\text { Scanty }\end{array}$ & $\begin{array}{l}\text { Extramedullary haemopoiesis } \\
\text { Extramedullary haemopoiesis }\end{array}$ \\
\hline $\begin{array}{l}\text { Scanty } \\
\text { Scanty } \\
\text { Scanty } \\
\text { Scanty }\end{array}$ & $\begin{array}{l}+ \\
- \\
+ \\
+ \\
+ \\
-\end{array}$ & $\begin{array}{l}- \\
- \\
+ \\
+ \\
+ \\
-\end{array}$ & $\begin{array}{l}\text { Erythroid } \\
\text { depression } \\
\text { Average } \\
\text { Average } \\
\text { Average }\end{array}$ & $\begin{array}{l}\text { Average (bud- } \\
\text { ding defect) } \\
\text { Scanty }\end{array}$ & Extramedullary haemopoiesis \\
\hline
\end{tabular}


the last-mentioned case (Case 11), where there was a maturation arrest of the megakaryocytes and erythroid hypoplasia. Of the 6 infants with icterus, one died before appropriate investigations could be done. The 5 survivors showed biochemical changes compatible with hepatocellular damage, with increase of both the direct and indirect fractions of the serum bilirubin. Histological examination of the liver in 3 cases showed increased extramedullary haemopoiesis for the age of the patient.

Special staining techniques failed to demonstrate spirochaetes in the organs of 3 patients who died. The results of blood cultures and tests for toxoplasmosis and cytomegalic inclusion body disease were negative in all cases.

\section{Discussion}

The association of syphilis with thrombocytopenia had not been noted before at Baragwanath Hospital, yet from our study we have concluded that syphilis is a most important cause of thrombocytopenia in the first three months of life among African infants admitted to this hospital. Clearly, awareness of this condition has led to a marked increase in the number of cases diagnosed.

The most recent case reports of congenital syphilis and thrombocytopenia appeared in 1936, when Josephs, reviewing anaemia of infancy, described 2 children with congenital syphilis, in whom thrombocytopenia and neutropenia were associated with a marked erythroblastosis and lymphocytosis. Necropsy showed replacement of the bone-marrow by a syphilitic connective tissue, and there was widespread extramedullary haemopoiesis. Josephs stressed the rarity with which syphilitic anaemia was seen at the Harriet Lane Hospital for children, and mentioned the paucity of reports of severe anaemia in congenital syphilis from the U.S.A.

Unlike Josephs' cases, our infants showed no replacement of the bone-marrow by syphilitic connective tissue. Haemolysis if present was minimal, the most severely anaemic cases having normal serum bilirubin levels.

The suppression of either megakaryocytes or platelets probably represents varying degrees of severity of the infection, and appears to be unrelated to the stage at which the marrow aspirates were studied after the commencement of therapy. The mechanism by which syphilis and infection in general causes thrombocytopenia is obscure. We postulate that the infection may either prevent the formation of megakaryocytes, or in some way interfere with marrow metabolism and so prevent the normal development of the platelet precursors.

The consequences of thrombocytopenia may be severe : 3 children died and 2 of these showed visceral bleeding at necropsy. A fourth child developed hydrocephalus secondary to intra-cranial bleeding during the acute stage of his illness. The remaining 11 patients recovered with full haematological remission. These severe complications and the good response to therapy make early diagnosis essential.

With the widespread reports of the reappearance of syphilis in many parts of the world, it is reasonable to expect that a proportion of bleeding and purpura in the newborn and young infant will be caused by this disease, especially among those communities where antenatal care is not adequate.

\section{Summary}

Thrombocytopenia complicating congenital syphilis is described in 15 cases. Syphilis is a most important cause of thrombocytopenia and bleeding during the first few months of life among African babies at Baragwanath Hospital. The severe complications which may attend the bleeding diathesis, and the good response to therapy make early diagnosis essential.

We are grateful to Dr. S. Wayburne and the Superintendent, Baragwanath Hospital, for permission to publish these case reports. We are indebted to Dr. R. Cassel of the S.A.I.M.R. for the haematological studies, and we gratefully acknowledge the helpful criticism of Dr. L. Taitz, Dr. S. E. Levin, and Dr. H. Stein.

\section{REFERENCES}

Britton, C. J. C. (1963). Whitby and Britton's Disorders of the Blood, 9 th ed. J. \& A. Churchill, London.

Dacie, J. V. (1956). Practical Haematology, 2nd ed., p. $23 . \quad$ J. \& A. Churchill, London.

Josephs, H. W. (1936). Anaemia of infancy and early childhood. Medicine (Baltimore), 15, 307.

Lathe, G. H., and Ruthven, C. R. J. (1958). Factors affecting the rate of coupling of bilirubin and conjugated bilirubin in the van den Bergh reaction. $\mathcal{F}$. clin. Path., 11, 155.

Mandel, E. F. (1962). Laboratory diagnosis of hemorrhagic disorders. In Todd-Sanford Clinical Diagnosis by Laboratory Methods, ed. I. Davidsohn and B. B. Wells, 13th ed., p. 334. Saunders, Philadelphia and London.

Shaffer, J. G., and Goldin, M. (1962). Serodiagnostic tests for syphilis. In Todd-Sanford Clinical Diagnosis by Laboratory Methods, ed. I. Davidsohn and B. B. Wells, 13th ed., p. 861 . Saunders, Philadelphia and London.

Smith, C. H. (1960). Blood Diseases of Infancy and Childhood, p. 142. C. V. Mosby, St. Louis.

Wintrobe, M. (1961). Clinical Hematology, 5th ed. Lea and Febiger, London and Philadelphia. 